\title{
The effect of four weeks restricted diet on serum soluble leptin receptor levels and adipocyte leptin receptor density in normoweight rattus norvegicus strain Wistar
}

\author{
M. Rasjad Indra*, Wibi Riawan ${ }^{f}$
}

\begin{abstract}
Abstrak
Salah satu mekanisme terjadinya resistensi leptin pada obesitas adalah kelainan reseptor leptin (Ob-R). Beberapa penelitian membuktikan bahwa aktifitas ikatan leptin di serum manusia berhubungan dengan reseptor leptin terlarut (soluble leptin receptor) dan restriksi asupan energi menyebabkan penurunan kadar leptin darah. Penelitian ini adalah untuk mengetahui beda kadar reseptor leptin terlarut serum dan densitas reseptor leptin di jaringan lemak adventitial aorta setelah dilakukan restriksi diet selama 4 minggu. Kadar reseptor leptin terlarut diukur dengan ELISA dan densitas reseptor leptin di jaringan lemak dengan imunohistokimia. Kadar reseptor leptin terlarut pada kelompok perlakuan 40\% diet normal lebih rendah dibanding kontrol $(p=0,02)$. Tidak didapatkan perbedaan reseptor leptin terlarut yang bermakna antara kelompok perlakuan 40\% diet normal, 1 hari puasa-1 hari makan normal dan 1 hari puasa-2 hari makan normal. Di sisi lain, densitas reseptor leptin di jaringan lemak adventitia aorta justru lebih tinggi pada kelompok restriksi $40 \%$ daripada kontrol. Restriksi diet $40 \%$ kalori normal harian menurunkan kadar reseptor leptin terlarut di serum, tetapi meningkatkan densitas reseptor leptin di jaringan lemak advential aorta tikus. Perubahan ini mungkin merupakan akibat mekanisme up regulation dalam mempertahankan homeostasis. (Med J Indones 2006; 15:145-50)
\end{abstract}

\begin{abstract}
One of the five possible mechanisms of leptin resistance in human obesity is the defect in the leptin receptor (Ob-R). Evidence has accumulated that leptin-binding activity in human serum is related to a soluble form of the leptin receptor, and restriction of energy intake resulted a decrease in circulating leptin levels. Aim of this study is to examine the difference of serum soluble leptin receptor level and leptin receptor density in rat adipose tissue of adventitial aorta after four weeks treated with different restricted diets. Soluble leptin receptor level was measured by ELISA and leptin receptor density by using immuno-histochemistry. The soluble leptin receptor in group treated with $40 \%$ of normal daily calori diet was found significantly lower than control $(p=0.02)$. There were no any significant differences among group treated with $40 \%$ of normal daily calori diet, "1 day fast-1 day eat", and " 1 day fast-2 days eat" groups, and among 1 day fast-1 day eat", "day fast - 2 days eat" and control groups as well. On the other hand, leptin receptor density in adipose tissues was higher in restricted diet group than control. Diet of $40 \%$ normal daily calorie for 4 weeks decreased soluble leptin receptor level, but increased adipocyte leptin receptor density of the adipose tissue of rat adventitial aorta. These changes may be resulted from an up regulation mechanism in relation with homeostatic maintenance. (Med J Indones 2006; 15:145-50)
\end{abstract}

Keywords: restricted diet, leptin receptor, soluble leptin receptor, adipocyte, obesity.

Obesity is the most common metabolic disorder in modern societies. Leptin, named from the Greek root leptos meaning thin, placed in the blood of mice and humans. It is believed that a significant portion of obesity can be traced back to abundant consumption

\footnotetext{
* Department of Physiology, Faculty of Medicine, Brawijaya University, Malang, Indonesia

$f$ Department of Biology, Faculty of Medicine, Brawijaya University, Malang, Indonesia
}

of tasty foods high in fat and dense in callory. Many researchers suggest that the majority of obese people are diet-induced obesity. A group of individual with mutations in the leptin receptor-will be totally refractory to leptin, and another group will be very sensitive to leptin, mainly those with relative hypoleptinemia.

Preliminary research indicates that people who successfully lost weight consume less than their total calories diet. ${ }^{1}$ Some currently popular restricted diet are the fat restrict diets. Others restrict carbohydrates, 
either to extremely low amounts as in the Atkins diet, or to a lesser degree, emphasizing foods low in the glycemic index or high in protein. However, there is no diet which proven effective for long-term weight loss, and many people find it difficult to stay on most restricted diets. ${ }^{2}$

Decrease in energy intake sustained over several weeks may play an important role in altering levels of plasma leptin. ${ }^{3}$ Leptin mRNA levels in adipose tissue per unit of fat mass are increased in 10-day-old Zucker rat pups in proportion to gene dosage for the functionally inactive leptin receptor. These effects of leptin receptor are independent of plasma insulin levels, suggesting that leptin expression in adipose tissue is subject to negative feedback regulation mediated by the leptin receptor instead of via mechanisms that directly dependent on SNS activity. ${ }^{4,5}$

The leptin receptor $(\mathrm{Ob}-\mathrm{R})$ is found in adipose tissues, hypothalamus, heart, and testes. This receptor has been shown to be product of $\mathrm{db}$ gene which has long been thought to encode the receptor for a weight controlling hormone.

Leptin receptors which abnormally spliced in $\mathrm{db} / \mathrm{db}$ mice and missing the cytoplasmic domain are thought to be important for leptin signaling. Evidence has accumulated that, at least in part, the leptin-binding activity in human serum is related to a soluble form of the leptin receptor as well. Leptin-binding components were shown to have immuno-reactivity with antibodies raised against a synthetic peptide of the leptin receptor extracellular domain.

Leptin receptor is expressed in adventitial aorta. ${ }^{6}$ Leptin however promotes angiogenic processes via activation of the endothelial $\mathrm{Ob}-\mathrm{R}$ by inducing a growth signal involving a tyrosine kinase-dependent intra-cellular pathway. ${ }^{7,8}$

Restriction of energy intake and weight loss is associated with decreased serum leptin levels. In healthy volunteers, a short-term fast resulted a decrease in circulating leptin levels that was disproportionately large to the extent of weight loss. Additionally, moderate caloric restriction resulted in a significant decrease in leptin levels. The bioactivity of circulating leptin may be affected by changes in the serum concentration of soluble leptin receptor, but currently there is little information available on the effect of intermediate-term caloric restriction on soluble leptin receptor.
The aim this research is to elucidate whether moderate restricted diet altering serum soluble leptin receptor levels and leptin receptor density in adipose tissue of adventitial aorta.

\section{METHOD}

\section{Animal and experimental design}

Male Rattus novergicus strain Wistar, nine months old and $250-300$ gram body weight, were kept at 23$24^{\circ} \mathrm{C}$ on $12: 12$ hours light-dark cycle. They were brought into the facility at 300-325 g research diet and water ad libitum for $1 \mathrm{wk}$ in animal house facility of Physiological Laboratory, Medical Faculty of Brawijaya University. This diet is composed of $8 \%$ corn oil, 44\% sweeten condensed milk, and $48 \%$ Purina rat chow. During this week, quantity and calorie daily diet were observed as a normal intake. Than, these rats were divided into four restricted diet groups (five rats each group) restricted $40 \%$ of normal daily calorie diet (RD40), 1day fast - 1day normal eat (Fast-1), 1day fast - 2 day normal eat (Fast-2); and ad libitum diet as a control (Ctr).

\section{Research Procedure}

Following four weeks of restricted diet program, for examination of serum soluble leptin receptor level all animals were sacrificed for examination of the density of leptin receptor in the adipose tissues of adventitial aorta. Blood was drawn from the heart immediately following sacrificing animal. Soluble leptin receptor level was measured by ELISA and leptin receptor density by using immuno-histochemistry.

\section{ELISA for Soluble Leptin Receptor Levels Examination}

Microtiter wells was coated with mouse monoclonal anti leptin receptor antibody. Sample and standards were incubated in microtiter wells for 1 hour. After a thorough washing, secondary antibody labeled with HRP wa added than incubated for 40 minutes in room temperature. After washing and an addition of TMB, reading were performed in within 15 minutes at $450 \mathrm{~nm}$ elisa reader.

\section{Immunohistochemistry for Leptin Receptor Density}

Paraffin section $(5 \mu \mathrm{m})$ of the adipose tissue were transferred to glass slide. Slide were deparaffinized 
and rehydrated through the following solutions: xylene twice for 5 minutes, $100 \%$ ethanol twice for 10 dips and 95\% ethanol twice for 10 dips. Endogenous peroxidase activity was blocked for 10 minutes at room temperature in $3 \% \mathrm{H} 2 \mathrm{O} 2$ in metanol and rinsed with $\mathrm{PBS}$ $\mathrm{pH}$ 7,4. Non-spesific protein binding sites were blocked by applying 5\% normal goat serum diluted in PBS/0.05\% Tween $20(\mathrm{pH}=7.2-7.4)$ to slides for 20 minutes at room temperature. The serum was blotted off and the primary antibody for leptin receptor (Ob-R) was diluted in $1 \%$ normal goat serum and PBS/0.05\% Tween 20. Applied and incubated overnight at $4^{\circ} \mathrm{C}$ in a humidity chamber. Antibodies directed againts the carboxyl (C-20) or the amino terminus (N-20) of Ob$\mathrm{R}$ recognized a $170 \mathrm{kDa}$ protein, the size of which is consistent with the rat leptin receptor.

On day 2, the primary antibody was rinsed off with PBS pH 7,4, blotted and the biotinylated secondary antisera cocktail goat anti-rabbit diluted $1 / 400$ was incubated on the slides for 1 hour at room temperature. Slides were rinsed in running tap water, blotted and streptavidin-horseradish peroxidase diluted 1/500 in PBS $/ 0.05 \%$ Tween 20 and $1 \%$ normal goat serum was applied and incubated for 40 minutes at room temperature. The slides were rinsed in tap water and color developed in DAB (Diamino Benzidine) substrate solution for 30 minutes at room temperature, then counterstained in Mayer Hematoxilen for 10 minutes and rinsed off in tap water and covered with coverslip.

Slides for immunohistochemistry analyzes were prepared from each animal of RD40 and control groups. Five spots were observed from each slide. Images were captured using Nikon digital camera Cool Pix 4500 then processed and analyzed using Corel Draw software version 11.

\section{Statistical Analysis}

The Student-T test was used to identify differences in soluble leptin receptor levels and leptin receptor density among group. Significance was set at $\mathrm{P}=0.05$. All statistical computations were conducted using SPSS version 11 software.

\section{RESULTS}

We examined the four restricted diet rat groups. The soluble leptin receptor of RD40 groups was significantly lower than control $(\mathrm{p}=0.02)$, but there were no significant differences among RD40, Fast-1, and Fast-2 groups, and among Fast-1, Fast-2 and control groups as well (Figure 1. and Table 1a and 1b). On the contrary, leptin receptor density in adipose tissues of the adventitia aorta were significantly higher in RD40 group than control (Figure 2, 3, and 4) and there were no significant differences among RD40, Fast-1, and Fast-2 groups and among Fast-1, Fast-2 and control groups (Table $2 a$. and $2 b$ ).

\section{DISCUSSION}

Previous studies in obese individuals have shown that restriction of energy intake and weight loss is associated with decreased serum leptin levels. ${ }^{9}$ In healthy volunteers who observed a short-term fast, there was a decrease in circulating leptin levels that was disproportionately large to the extent of weight loss. ${ }^{10,11}$ Additionally, moderate caloric restriction resulted in a significant decrease in leptin levels in healthy volunteers, ${ }^{12,13}$ although the effect of more extended dieting were studied less extensively. The bioactivity of circulating leptin may be affected by changes in the serum concentration of sOB-R. ${ }^{14,15}$ Currently, there is little information available on the effect of modest caloric restriction on sOB-R levels in healthy volunteers.

With respect to the effect of modest caloric restriction on leptin levels, an initial study showed that a 3 day diet with a $30 \%$ restriction in energy intake in healthy male volunteers resulted in a $22 \%$ decrease in leptin levels. ${ }^{16}$ The current study extends these findings by showing that a modest reduction in energy intake over 4 weeks in healthy women was associated with a marked $60.3 \%$ decrease in plasma leptin levels and that, in spite of the relatively narrow range of weight change, there was a highly significant correlation between change in leptin and change in body weight.

In previous studies, plasma sOb-R concentrations did not change significantly in women studied after $22 \mathrm{~h}$ of fasting, ${ }^{17}$ but did increase in male volunteers following a $72 \mathrm{~h}$ fast, ${ }^{18}$ and in obese patients following weight loss. ${ }^{19}$ This study provides new data demonstrating that a more prolonged, less pronounced energy restricted diet increases circulating levels of sOb-R in healthy, normal-weight female volunteers. This finding suggests that the increase in sOb-R levels observed in anorexia nervosa may be a result of energy restriction and weight loss. ${ }^{20,21,22}$ 


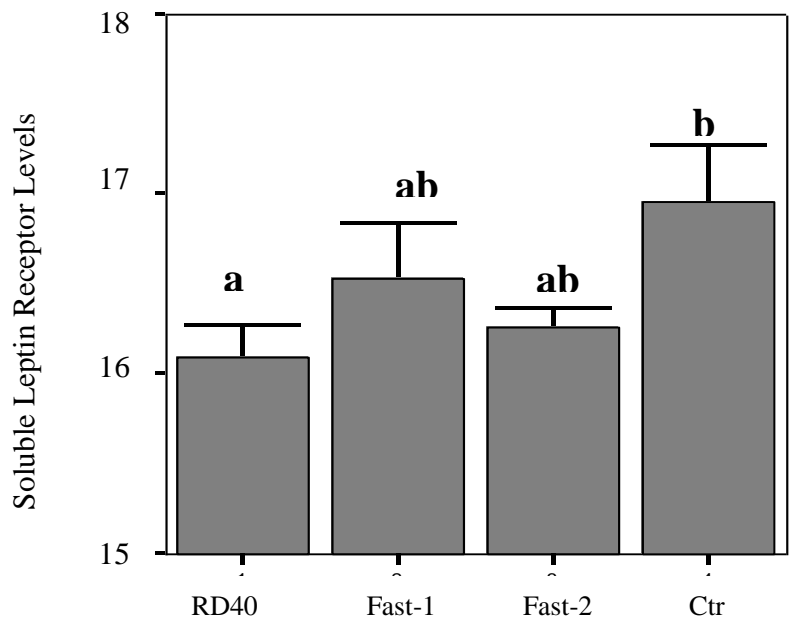

Figure 1. Serum sOb-R levels in four restricted diet groups

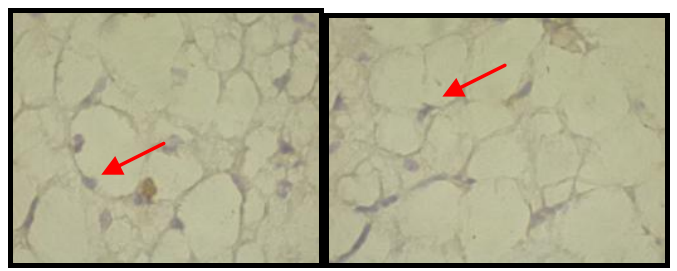

Figure 2. Leptin receptor density in adipose tissue of control group
Table 1a. Soluble Leptin Receptor Levels (ng / mL) in Four Restricted Diet Group

\begin{tabular}{|c|c|c|c|}
\hline \multicolumn{2}{|c|}{ Group } & Mean & SD \\
\hline RD40 & $\begin{array}{c}\text { Restricted } \\
\text { diet 40 \% }\end{array}$ & $16.102 *$ & 0.412 \\
\hline Fast-1 & $\begin{array}{c}\text { One day } \\
\text { fast-one } \\
\text { day off }\end{array}$ & 16.530 & 0.745 \\
\hline Fast-2 & $\begin{array}{c}\text { One day } \\
\text { fast- two } \\
\text { days off }\end{array}$ & 16.260 & 0.252 \\
\hline Ctr & Control & 16.963 & 0.707 \\
\hline
\end{tabular}

Table 1b. Student-t test significances between groups

\begin{tabular}{|l|l|l|l|}
\hline & \multicolumn{1}{|c|}{ Fast-1 } & \multicolumn{1}{|c|}{ Fast-2 } & \multicolumn{1}{|c|}{ Ctrl } \\
\hline RD40 & $\begin{array}{l}\mathrm{p}=0.198 \\
\text { (ns) }\end{array}$ & $\begin{array}{l}\mathrm{p}=0.621 \\
(\mathrm{~ns})\end{array}$ & $\begin{array}{l}\mathrm{p}=0.02 \\
(\mathrm{~s})\end{array}$ \\
\hline Fast-1 & & $\begin{array}{l}\mathrm{p}=0.416 \\
(\mathrm{~ns})\end{array}$ & $\begin{array}{l}\mathrm{p}=0.219 \\
(\mathrm{~ns})\end{array}$ \\
\hline Fast-2 & & & $\begin{array}{l}\mathrm{P}=0.053 \\
(\mathrm{~ns})\end{array}$ \\
\hline
\end{tabular}

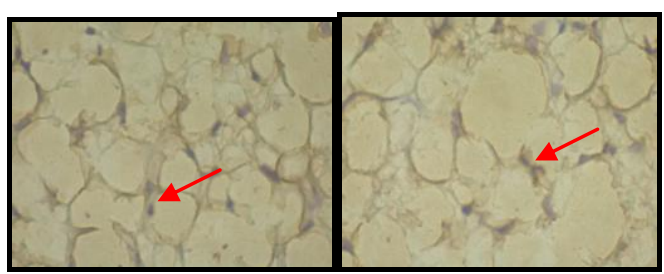

Figure 3. Leptin receptor density in $40 \%$ of normal daily diet group (RD40)

Leptin receptor expression (arrow) was less dense in control group (Figure 2. A and B) than in 40\% of normal daily diet group (RD40) (Figure 3. A and B). The difference was shown by different density between two group in which RD40 group were more dense than control.

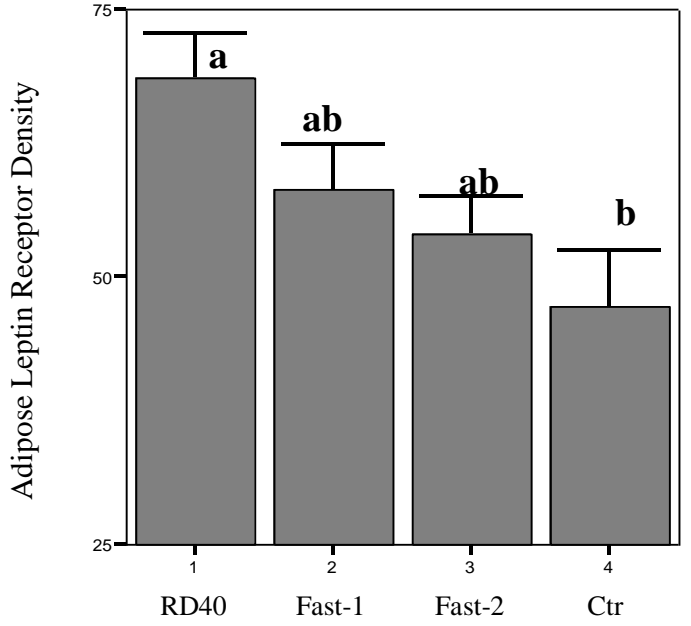

Figure 4. Leptin receptor density in adipose tissue
Table 2a. Leptin receptor density in adipose tissue of adventitial aorta (Using Corel Draw Software)

\begin{tabular}{|l|l|c|c|}
\hline \multicolumn{2}{|c|}{ Group } & Mean & SD \\
\hline RD40 & $\begin{array}{l}\text { Restricte diet } \\
40 \%\end{array}$ & 68,64 & 20,477 \\
\hline Fast-1 & $\begin{array}{l}\text { One day fast- } \\
\text { one day off }\end{array}$ & 58,20 & 20,708 \\
\hline Fast-2 & $\begin{array}{l}\text { One day fast- } \\
\text { two days off }\end{array}$ & 54,05 & 15,921 \\
\hline Ctr & Control & 47,26 & 26,962 \\
\hline
\end{tabular}

Tabel 2b. Student-t test Significances between groups

\begin{tabular}{|l|l|l|l|}
\hline RD40 & \multicolumn{1}{|c|}{ Fast-1 } & \multicolumn{1}{|c|}{ Fast-2 } & \multicolumn{1}{|c|}{ Ctrl } \\
\hline Fast-1 & $\begin{array}{l}\mathrm{p}=0.092 \\
\mathrm{~ns})\end{array}$ & $\begin{array}{l}\mathrm{p}=0.063 \\
(\mathrm{~ns})\end{array}$ & $\begin{array}{l}\mathrm{p}=0.01 \\
(\mathrm{~s})\end{array}$ \\
\hline Fast-2 & & $\begin{array}{l}\mathrm{p}=0.513 \\
\text { (ns) }\end{array}$ & $\begin{array}{l}\mathrm{p}=072 \\
(\mathrm{~ns})\end{array}$ \\
\hline & & $\begin{array}{l}\mathrm{P}=0.275 \\
(\mathrm{~ns})\end{array}$ \\
\hline
\end{tabular}


The results of numerous studies suggest that body weight is regulated within a specific range. When lean or obese weight subjects were underfed to achieve a $7.5-10 \%$ change in body weight, total energy expenditure (TEE) decreased by $<12-15 \% .^{23-24}$ Other physiologic changes induced by energy restriction include increased hunger and down-regulation of neuro-endocrine functions. ${ }^{25-29}$ These adaptations together may act to antagonize further weight loss. Genetic factors are known to influence the range in which body weight is regulated. ${ }^{30}$ However, the increasing prevalence of obesity among genetically stable populations ${ }^{31}$ indicates that environ-ment must also play an important role in the regulation of body weight.

Experiments using human umbilical venous endothelial cells demonstrated that treatment of HUVECs with leptin enhanced formation of capillary-like tubes in an in vitro angiogenesis assay and neovascularization in an in vitro model of angiogenesis. These results indicated that leptin, via activation of the endothelial $\mathrm{Ob}-\mathrm{R}$, generated a growth signal involving a tyrosine kinase-dependent intracellular pathway and promoted angiogenic processes.

Restricted diet conducted in this research could be classified as an moderate restricted diet program, in which adaptation mechanism yielded decrease in soluble leptin receptor as a transport system and increasing leptin receptor as the compensatory mechanism. The limitation of this study was that we did not used enough animal each group, five rat instead of six according to Federer formula.

It was suggested that decreasing sOb-R related to low serum leptin level in intermediate-term low energy condition are an adaptation process which followed by increased leptin receptor in target tissues as an up regulation.

\section{CONCLUSION}

Restricted diet $40 \%$ of normal daily calorie for four weeks in rat caused a decrease in serum soluble leptin receptor level and an increase in leptin receptor density in adipose tissue of adventitia aorta. The present study is a preliminary restricted diet research on adventitial aorta adipose tissue and opens a promising perspective concerning future investigations of leptin-dependent modulation of atherogenesis and vascular neovascularization under pathophysiological conditions.

\section{REFERENCES}

1. Andersson I, Lennernas M, Rossner S. Meal pattern and risk factor evaluation in one-year completers of a weight reduction program for obese men-the study. J Intern Med 2000;247:30-8.

2. Miller WC. How effective are traditional dietary and exercise interventions for weight loss? Med Sci Sports Exerc 1999;31:1129-34 [review].

3. Barbara E. Wolfe*, David C. Jimerson*, Christine Orlovat and Christos S. Mantzoros. Effect of dieting on plasma leptin, soluble leptin receptor, adiponectin and resistin levels in healthy volunteers. Clinical Endocrinology 2004; 61:332-8.

4. Zhang Y, Olbort M, Schwarzer K, Nuesslein-Hildesheim B, Nicolson M, Murphy E, Kowalski TJ, Schmidt I, and Leibel RL. The leptin receptor mediates apparent autocrine regulation of leptin gene expression. Biochem Biophys Res Commun 1997:240;492-5.

5. Zhang Y, Carmen H, Sandra E, Kai-Ying G, Patricia AD, Rudolph L, Ingrid S. Mechanisms for LEPR-mediated regulation of leptin expression in brown and white adipocytes in rat pups. Physiological Genomics 2001; 4:189-99.

6. Seok-Min kngl, Hyuck Moon won', Bum Kee H-', hngsoo im',In Jai Kim', Eui Young choil, Yangsoo .Iang', HyunSang irn', Myung Sin im', and Hyuck Chm ICwn2. Expression of Leptin Receptor (Ob-R) in Human Atherosclerotic Lesions: Potential Role in Intirnal Neovasdarization, Yonsei Medical Journal 2000;41:68-75.

7. Bouloumie A, Drexler HCA, Lafontan M, Busse R Leptin, the product of $\mathrm{Ob}$ gene, promotes angiogenesis. Circ Res 1998;83:1059-66.

8. Tartagia L. The leptin receptor. J Biol Chem 1997;272: 6093-6.

9. Maffei M, Halaas J, Ravussin E, Pratley RE, Lee GH, Zhang Y, et al. Leptin levels in human and rodent: measurement of plasma leptin and ob RNA in obese and weight-reduced subjects. Nature Medicine 1995;1:1155-61.

10. Boden G, Chen X, Mozzoli M, Ryan I. Effect of fasting on serum leptin in normal human subjects. J Clin Endocrinol Metab 1996;81:3419-23.

11. Kolaczynski JW, Considine RV, Ohannesian J, Marco C, Opentanova I, Nyce MR, et al. Responses of leptin to short-term fasting and refeeding in humans. A link with ketogenesis but not ketones themselves. Diabetes 1996; 45:1511-15.

12. Dubuc, GR, Phinney, SD, Stern, JS, Havel, PJ. Changes of serum leptin and endocrine and metabolic parameters after 7 days of energy restriction in men and women. Metabolism 1998; 47:429-34.

13. Chin-Chance C, Polonsky KS, Schoeller DA. Twentyfourhour leptin levels respond to cumulative short-term energy imbalance and predict subsequent intake. J Clin Endocrinol Metab 2000; 85:2685-91.

14. Brabant G, Horn R, von zur MA, Mayr B, Wurster U, Heidenreich $\mathrm{F}$, et al. Free and protein-bound leptin are distinct and independently controlled factors in energy regulation. Diabetologia 2000;43:438-42.

15. Lammert A, Kiess W, Bottner A, Glasow A, Kratzsch J. Soluble leptin receptor represents the main leptin binding 
activity in human blood. Biochemical and Biophysical Research Communications 2001;283:982-8.

16. Landt M, Horowitz JF, Coppack SW, Klein S. Effect of short-term fasting on free and bound leptin concentrations in lean and obese women. J Clin Endocrinol Metabol 2001;86:3768-71.

17. Chan JL, Bluher S, Yiannakouris N, Suchard MA, Kratzsch J, Mantzoros CS. Regulation of circulating soluble leptin receptor levels by gender, adiposity, sex steroids, and leptin: observational and interventional studies in humans. Diabetes 2002;51:2105-12.

18. Laimer M, Ebenbichler CF, Kaser S, Sandhofer A, Weiss $\mathrm{H}$, Nehoda $\mathrm{H}$, et al. Weight loss increases soluble leptin receptor levels and the soluble receptor bound fraction of leptin. Obesity Research 2002;10:597-601.

19. Kratzsch J, Lammert A, Bottner A, Seidel B, Mueller G, Thiery J, et al. Circulating soluble leptin receptor and free leptin index during childhood, puberty, and adolescence. J Clin Endocrinol Metab 2002; 87: 4587-94.

20. Krizova J, Papezova H, Haluzikova D, Parizkova J, Jiskra, J, Kotrlikova E, et al. Soluble leptin receptor levels in patients with anorexia nervosa. Endocrine Research 2002;28:199-205.

21. Monteleone P, Fabrazzo M, Tortorella A, Fuschino A, Maj M. Opposite modifications in circulating leptin and soluble leptin receptor across the eating disorder spectrum. Molecular Psychiatry 2002;7:641-6.

22. Leibel RL, Rosenbaum M, Hirsch J. Changes in energy expenditure resulting from altered body weight. $\mathrm{N}$ Engl $\mathrm{J}$ Med 1995; 332:621-8.

23. Rosenbaum M, Ravussin E, Matthews DE, et al. A comparative study of different means of assessing long- term energy expenditure in humans. Am J Physiol 1996; $270: 496-504$.

24. Valtuena S, Blanch S, Barenys M, Sola R, Salas-Salvado J. Changes in body composition and resting energy expenditure after rapid weight loss: is there an energymetabolism adaptation in obese patients. Int J Obes Relat Metab Disord 1995; 19:119-25.

25. Velthuis-te Wierik EJ, Westerterp KR, van den Berg H. Impact of a moderately energy-restricted diet on energy metabolism and body composition in non-obese men. Int $\mathbf{J}$ Obes Relat Metab Disord 1995;19:318-24.

26. Kibanski A, Beitins IZ, Badger T, Little R, McCarthur JW. Reproductive function during fasting in men. J Clin Endocrinol Metab 1981;53:258-63.

27. Fichter MM, Pirke KM, Holsboer F. Weight loss causes neuroendocrine disturbances: experimental study in healthy starving subjects. Psychiatry Res 1986;17:61-72.

28. Vagenakis AG, Burger A, Portnary GI, et al. Diversion of peripheral thyroxine metabolism from activating to inactivating pathways during complete fasting. J Clin Endocrinol Metab 1975;41:191-4.

29. Jung RT, Shetty PS, James WP. Nutritional effects on thyroid and catecholamine metabolism. Clin Sci 1980;58:183-91.

30. Rosenbaum M, Leibel RL, Hirsch J. Obesity. N Engl J Med 1997;337:396-407.

31. Kuczmarski RJ, Flegal KM, Campbell SM, Johnson CL. Increasing prevalence of overweight among US adults. The National Health and Nutrition Examination Surveys, 1960 to 1991 . JAMA $1994 ; 272: 205-11$. 